\title{
Violencia y destrucción del orden en Cualquier forma de morir, de Rafael Menjívar ${ }^{1}$
}

\author{
(Violence and Destruction of Order in \\ Cualquier forma de morir, by Rafael \\ Menjívar)
}

\section{Gabriel Baltodano Román ${ }^{2}$}

Universidad Nacional, Costa Rica

\begin{abstract}
resumen
Se analizan los simbolismos de la novela Cualquier forma de morir (2006), del escritor salvadoreño Rafael Menjívar (1959-2011). Esta novela negra contemporánea trata acerca de la destrucción del orden social por causa de la violencia del narcotráfico. En el relato, priva una perspectiva determinada por el empleo de imágenes propias del mito, en particular, una visión apocalíptica de la sociedad mexicana. Tal recurso al mito forma parte de una tendencia común en la nueva ficción criminal hispanoamericana.
\end{abstract}

\begin{abstract}
This article addresses the symbolism in the novel Cualquier forma de morir (2006), by Rafael Menjívar (El Salvador; 1959-2011). This contemporary black novel deals with the destruction of social order due to violence from drug trafficking. As the novel unfolds, the prevailing perspective is determined by the presence of images corresponding to the myth, in particular, of an apocalyptic view of Mexican society. That use of the myth is part of a common tendency in new Latin American crime fiction.
\end{abstract}

1 Recibido: 7 de enero 2014; aceptado: 12 de febrero de 2014.

2 Escuela de Literatura y Ciencias del Lenguaje. Correo electrónico: gabriel.baltodano.roman@una.cr

$$
L_{\text {etras }} 55 \text { (2014), ISSN 1409-424X; eISSN 2215-4094 }
$$


Palabras clave: Literatura salvadoreña, narrativa hispanoamericana, novela contemporánea, novela negra, Rafael Menjívar (El Salvador, 1959-2011) Keywords: Salvadoran literature, Hispanic narrative, contemporary novel, thriller, Rafael Menjívar (El Salvador, 1959-2011)

La novela hispanoamericana contemporánea no escapa de ciertas influencias fundamentales; el mito ocupa un lugar primordial entre ellas. El encuentro de la novela con el mito ha sido examinado en diversas oportunidades y a lo largo de los últimos tres siglos. Diversos historiadores de la cultura y la literatura comparada han insistido en un hecho: las creencias y narraciones de los pueblos antiguos brindan un retrato profundo de las inquietudes colectivas y el conocimiento ancestral acerca de la condición humana.

En nuestros días, bien se trata de un acervo conveniente para el novelista, una colección de tramas, figuras y explicaciones dispuestas ante el escritor, quien las puede usar con solemnidad, pero también con desenfado. En la novela Cualquier forma de morir, de Rafael Menjí$\operatorname{var}^{3}$ se emplean elementos procedentes de mitologías prehispánicas y doctrinas religiosas occidentales. La alusión a la decadencia permite a su autor recrear uno de los más importantes procesos sociales de la región.

Menjívar utiliza la imaginación literaria para discutir acerca del predominio de la violencia en la historia moderna de México, para afirmar que la vorágine desatada por el narcotráfico, durante los últimos lustros, ha llevado al Estado, el sistema político y la sociedad al borde de la desintegración. Menjívar acude a los mitos sobre el fin del mundo y el advenimiento de un nuevo orden. En su caso, no existe libertad al final de los tiempos, sino barbarie.

3 Rafael Menjívar (El Salvador, 1959-2011) ejerció el periodismo y se desempeñó como traductor. En 1973 marchó al exilio en Costa Rica; estudió en México y regresó a su país en 1999. Publicó las siguientes novelas: Historia del traidor de Nunca Jamás (1985), Los años marchitos (1990), De vez en cuando la muerte (2002), Trece (2003), Un buen espejo (2005), Cualquier forma de morir (2006), Instrucciones para vivir sin piel (2008) y Los héroes tienen sueño (2008). La mayoría de estos relatos fueron compuestos bajo el subgénero de la novela negra. 
En este y otros textos análogos, la novela hispanoamericana se nutre de las mitologías cristiana y precolombina. El subgénero de la novela negra conserva, en sus expresiones recientes, los viejos ligámenes con lo asombroso y lo extraordinario, aunque se adapta a nuevos repertorios. El gusto por los enigmas y la búsqueda de realidades profundas, desprovistas de los engañosos ropajes de la cotidianidad, determinan la función explicativa de este tipo de narraciones.

Ante la indescifrable pregunta por el porvenir de América Latina, algunos escritores contestan mediante las imágenes acumuladas por la tradición de los augurios. La historia, objeto último de estas pesquisas mayores, que no reparan solo en crímenes sórdidos e individuales, es interpretada mediante el mito. La indagación en torno a la violencia promovida por el narcotráfico, como se propone en Cualquierforma de morir, parte de simbolismos religiosos y antiguos acerca del devenir temporal y su vínculo con la vida social y el declive de las civilizaciones.

La realidad de estas concepciones tiene como sustento la repetición de eventos arquetípicos y paradigmáticos. El retorno a lo sagrado, aunque pueda ser entendido como un rasgo de la mentalidad ancestral casi extinta, cumple una función distintiva en la época contemporánea. No se trata de imitar los actos de la fundación, sino de abolir el tiempo. Según Mircea Eliade ${ }^{4}$, «la memoria colectiva es ahistórica», esto supone que solo lo ejemplar puede ser recordado por las capas populares. La individualidad del evento histórico, su sentido específico, se escapan, por lo general, a la mentalidad de los grandes grupos sociales; incluso en la actualidad, la conciencia de la mayoría se funda en una «ontología arcaica». De acuerdo con Eliade, «podría decirse que la memoria popular restituye al personaje histórico de los tiempos modernos su significación de imitador del arquetipo y de reproductor de imágenes arquetípicas».

Este fenómeno define el gusto y los esquemas de consumo de amplios sectores. La ficción criminal ha sido, a lo largo de su historia,

4 Mircea Eliade, El mito de eterno retorno. Arquetipos y repetición. Trad. R. Anaya (Madrid: Alianza, 2009) 51. 
un género de alta aceptación. Nace con la prensa decimonónica, una de las primeras formas de la comunicación masiva; nace como literatura acerca de la vida urbana, capitalista e industrial. El regreso al arquetipo se vislumbra en otras tantas manifestaciones del consumo globalizado, también los tebeos y muchas películas recientes comparten una lógica semejante.

Por otro lado, la oposición ante el concepto de historia como cadena de sucesos impredecibles, autónomos e irreversibles se relaciona con el pensamiento característico de la época posmoderna. Comprender el tiempo bajo la analogía del ciclo permite al hombre contemporáneo lidiar con el «terror a la historia». La supervivencia del mito del eterno retorno provoca disonancia, según lo explica Eliade 5 . El ser humano moderno se diferencia del hombre de las civilizaciones tradicionales por su comprensión del proceso histórico, en tanto se visualiza a sí mismo como agente creador de la historia.

El mundo moderno no obedece, por completo, al historicismo. El legado de Hegel, la historia como progreso, se opone a la concepción arcaica. Las teorías de los ciclos no solo descansan en atávicas supercherías, una buena parte de sus argumentos proceden de la observación de los astros. Los tratados científicos de los siglos $\mathrm{xv}$ y xvi influyeron. En la actualidad, tanto las tesis recientes sobre el origen del universo como aquellas referidas al término de la historia se contraponen al concepto lineal del tiempo. Según Eliade:

Esas orientaciones menosprecian no sólo al historicismo, sino también a la historia como tal. Creemos estar autorizados para descubrir en ellas, más que una resistencia a la historia, una rebelión contra el tiempo histórico, una tentativa para reintegrar ese tiempo histórico, cargado de experiencia humana, en el tiempo cósmico, cíclico e infinito ${ }^{6}$. 
La abolición del tiempo y el terror a la historia es una de las obsesiones de los literatos a lo largo del siglo xx. Marcel Proust (Francia, 1871-1922), James Joyce (Irlanda, 1882-1941) y T. S. Eliot (Estados Unidos, 1888-1965), cumbres de las letras modernas, dedicaron buena parte de sus obras literarias al examen de estos asuntos. El imperio del discurso unilateral de la razón ha dado lugar, según propone Bauzá7, a un acto subversivo: el aluvión de la irracionalidad. La búsqueda de otra clase de conocimiento ha ocasionado que los escritores encuentren en el mito un poderoso medio para la interpretación de la compleja realidad circundante.

Las utopías ilustradas son percibidas, paradójicamente, como grandes relatos; quizás, como los más irreales de cuantos se puedan contar. Frente a las pretensiones del pensamiento científico, prorrumpe la subjetividad y las intuiciones, que de manera críptica ensayan respuestas a las preguntas por el porvenir de Latinoamérica. Entre las inquietudes de los pensadores posmodernos figura el afán por descartar la universalidad de lo racional; en su lugar, se levanta el mito, un medio de comprensión que se ofrece tanto más abarcador que el pensamiento lógico ${ }^{8}$.

El lenguaje poético comparte con el mito la capacidad de recuperar la totalidad, de integrar las diferentes circunstancias del mundo. Las investigaciones emprendidas por el protagonista de la novela negra de Menjívar conducen al lector a un conocimiento particular acerca del mundo. Ese saber es semejante al de la revelación y la profecía; no es comprensible mediante los esquemas racionales, pues acude al mito para su ciframiento.

La representación de América Latina como un ámbito en crisis no procede, en exclusiva, de los violentos procesos sociales experimentados en la región. La lectura sociológica podría inadvertir el síntoma cultural. Este tipo de literatura corresponde con un giro de la

7 Hugo Francisco Bauzá, Qué es un mito. Una aproximación a la mitología clásica (México: Fondo de Cultura Económica, 2005) 234.

8 Bauzá, 235. 
imaginación: el escritor hispanoamericano, condicionado por el discurso acerca del entorno inmediato, la identidad y el historicismo, se resiste y prueba otras variedades narrativas con un contenido accesible a la sensibilidad posmoderna, adepta a lo sensible e irracional.

\section{Simbolismos de Cualquier forma de morir}

La boca de la pistola se veía grande y demasiado oscura. Nunca se sabe lo que pueda haber dentro de algo tan oscuro (43) ${ }^{9}$.

Pétrea expresión de horror en la mirada, una calavera observa desde el seno y recuerda el instante perdido. En los ojos se percibe el estremecimiento que ocasiona la llegada de la muerte. Apática ante el reclamo que resuena en las dos cuencas vacías y jóvenes, vestida para el caso, Coatlicue, diosa sedienta de sangre, recoge en sus atavíos, además de esta cabeza sin cuerpo, los muchos corazones de víctimas sacrificadas en el templo; y por su falda descienden mil serpientes. Madre inusual, crió con sus garras a más de cuatrocientos hijos. Atenta a las órdenes de su esposo, Mixcóatl, enseñó a cada uno las artes de la conspiración y el acecho. Divino y luminoso, pero temido, Huitzilopochtli, dios del sol y de la guerra del imperio, aprendió desde el vientre la lección. Hijo de la deshonra, sus hermanos lo odiaron desde el origen y, guiados por Coyolxauhqui, decretaron su exterminio. Pudo más su temperamento y destino; desde entonces, la cabeza de la hermana insidiosa recorre el cielo de Tenochtitlán y vela el sueño de los mexicas, para quienes resulta poco el pago por tantos favores: violencia y sangre.

No se trata de una escultura dispuesta en el patio de un museo de antropología; es una realidad, un mito que persiste. «Todo estaba oscuro. Se estaban gastando la electricidad del reclusorio. Había luna llena, pero no llegaba a alumbrar la celda» (9), afirma el narrador a

9 Las citas de la novela estudiada se indican mediante el número de página entre paréntesis, provienen de la siguiente edición: Rafael Menjívar, Cualquier forma de morir (Guatemala: F\&G Editores, 2006). 
propósito de un México tenebroso, contemporáneo y siempre vasallo, no ya de las pasiones de dioses impetuosos sino de la sed de carteles vengativos. México como una cárcel, como un lugar supeditado a la crueldad y el crimen; este es el espacio descrito por la novela de Rafael Menjívar.

En Cualquier forma de morir, el narcotráfico ocupa el sitial de la deidad y reclama inmolaciones. La luna, figura femenina ${ }^{10}$, no ofrece indulgencia ni amor a esta nación. Su fulgor ha cedido; no hay lugar para la belleza en este mundo profundamente masculino, donde las mujeres no son personaje. Ella tan solo anuncia el inicio de un nuevo periodo, de un ciclo más atroz que el anterior; anuncia la hora de la ofrenda. Al final, su inútil llanto persiste: «La luna estaba gritando» (115) se lee en la última línea de la novela; significa que la sangre colma el depósito de combustible del autómata. Este soberano terrible requiere de la muerte para ligar a sus amigos y para atar a sus rivales. Como tirano sanguinario, el narcotráfico redoma voluntades, acalla conciencias y corrompe la justicia. Bajo su poder no existe orden, tan solo maquinaria; la ley se convierte en una farsa; la existencia, desligada de lo ordinario y de la norma, adquiere un sentido irreal, mágico, diabólico. La concentración del poder y su brutalidad hacen que el triunfo sobre los combatientes se comprenda como evidencia de fuerza sobrenatural. Solo esta clase de terror da sentido al mundo, pues encadena a los hombres entre sí.

El escrito empieza con la descripción de la vida del narrador en el centro penal, sitio donde los hermanos Celis - una temible pareja de narcotraficantes- aguardan no justicia, sino tiempos seguros, libres de los ajustes de cuentas que el reacomodo de líderes provoca en el exterior. La actitud es festiva y se asemeja a una lupercal:

Serían las tres de la mañana y la música sonaba a orquesta de locos en el bloque de los Celis. Era la segunda fiesta de marzo, y apenas estábamos a mediados de mes. En febrero habían sido tres, y en

10 Ver Mircea Eliade, Imágenes y símbolos. Trad. C. Castro (Madrid: Taurus, 1999) 138. 
enero ninguna, porque los habían encarcelado el día treinta. Cada una era más ruidosa que la anterior, y ponía cada vez más nerviosos a los presos y a los guardias (9).

Rodeado por lobos, $\mathrm{N}$-que así denominaremos al narrador en adelante, pues no recibe etiqueta semántica alguna-debe, primero, penetrar en el corazón de las tinieblas y esclarecer las confusiones, para luego descubrir la decadencia y adquirir los medios para sobrevivir. A medio camino entre la serie negra y la picaresca, el texto muestra los senderos que han de transitar aquellos que, lejos de las apariencias y cerca de los márgenes, comprenden cuán útil resulta el pragmatismo en un medio caracterizado por el culto al dinero fácil y la caducidad de todo patrón moral.

En un entorno semejante, el ser humano está supeditado a la supervivencia, sus ideas no sirven para nada, solo prevalece sobre su conciencia el imperativo de postergar la muerte. El valor de la vida se torna relativo cuando se debe escoger entre la ajena y la propia; la unidad social se desmorona, las instituciones se convierten en ruinas; el Estado mismo parece sucumbir ante el crimen organizado y su ferocidad. La vida es tan solo un camino hacia la muerte; entre si se la asume con coraje o con servilismo no hay diferencia, pues supone, en exclusiva, variar el plazo y la forma de morir.

Las meditaciones de $\mathrm{N}$ apuntan hacia estos temas; así, por ejemplo, comenta que: «Todos se asombran cuando se enteran en los documentales de la segunda guerra mundial sobre los montones de judíos que se metían tranquilamente en la cámara de gas. Muchos hasta se sonreían y parecía que los estuvieran llevando a una fiesta». Y continúa: «Quizá hasta les habían dicho lo que les iba a pasar, pero se metían en la cámara sin hacer drama» (63). La existencia pasiva, la ausencia de oposición, la fortaleza no del consenso sino del asenso suponen, en suma, los principales asuntos. 


\section{Las muertes ocasionales}

La gente se pasa toda la vida teniéndole miedo a la muerte, y a la hora de las horas se da cuenta de que no era para tanto. $\mathrm{O}$ ni siquiera se da cuenta y hasta se la pasa bien en lo que se va al carajo. Claro que uno no es experto mientras no le toque por lo menos una vez, y con esa es suficiente (63).

Durante la noche, uno de los personajes principales, el Ciego, asesina con un cuchillo al Cura. Ambos comparten calabozo con el narrador, que tiene cuatro meses encarcelado. Este suceso viene a complicar la situación del protagonista:

Lo último que necesitaba era un acuchillado en la celda. Estaba acusado de matar a la mujer a cuchilladas y eso no me iba a ayudar. Yo no la había matado, pero allí estaba la confesión, con firma y todo. Hay gente que se toma en serio las confesiones firmadas (14).

N desempeña la función de chivo expiatorio, ha sido elegido para servir como sacrificio. La condición social de $\mathrm{N}$ lo hace idóneo. No tiene una familia que se preocupe por él, pues han muerto su madre y abuela, no conoce al padre y los primos lo desprecian; es una especie de huérfano, carece de amigos o pareja; por tanto, se puede interpretar que plantea una alegoría acerca de la soledad y la existencia humana en la época contemporánea. Además, su oficio de policía antinarcóticos lo acerca al mundo del trasiego de estupefacientes, lo convierte en presa de los intereses y el encanto del dinero.

La novela empieza con la ruptura de los límites entre la policía y los criminales, entre culpables e inocentes, entre perseguidor y perseguido. Además, muestra a unos narcotraficantes que toman vacaciones en la prisión, mientras que la policía y los asesinos a sueldo resuelven sus conflictos. Adentro, están todos mezclados, confundidos entre sí. No resulta sencillo saber con quién se traba amistad o con quién se discute. La modelización del espacio como 
un sitio cerrado advierte sobre la existencia de un mundo autónomo, regido por reglas y seres distintos. Asimismo, el principio de que el $\mathrm{N}$ sea un prisionero recuerda la condición de los condenados y el imaginario sobre el infierno, puesto que allí conviven los asesinos y los depravados. En este sentido, resulta de interés la manera en que son introducidos los diferentes personajes del relato. El Cura lleva a pensar en un fraile de película, según lo describe N. El sentido de esta alusión a una figura de la iglesia resulta negativo si se lo asocia con las connotaciones de la frase adyacente «de película», esto es, en apariencia, no realmente.

El Cura es el más antiguo de los prisioneros; manda en la cárcel y toma las decisiones: «El Cura era feliz encarcelado. Decía que no entendía cómo la gente soportaba vivir afuera» (11). Además, parece que se deleita infringiendo dolor y angustia a otros recluidos, por ejemplo, al Ciego, quien acaba por asesinarlo a causa de esto: «Tarde o temprano el Ciego tenía que cansarse de lo mal que lo trataba. Si hubieran estado casados, hubiera conseguido el divorcio por crueldad innecesaria» (14). Incluso, herido de muerte, el Cura se regodea: «-Lo enojé -dijo-. Por fin lo enojé» (15). ElCiego purga una condena pues mató a su propia hermana.

El Cura nunca duerme; tiene una caja que le causa melancolía, un simbolismo de la memoria; es cambiante y listo «como diablo viejo» (77). Otros rasgos confirman esta asociación con la figura del demonio: por una parte, a pesar de las cuchilladas del Ciego, el Cura vuelve de la muerte; por otra, conforme se desarrolla el relato, se descubre que ocupa un lugar central, pues lidera el cartel. De la misma forma, es él quien se encarga de dividir a los hermanos Celis y de reclutar a $\mathrm{N}$ para su bando.

Los Celis también habitan el reclusorio; son descritos como fieras y demonios. De Santiago, el hermano mayor, se afirma que tiene colmillos afilados de lobo; en tanto que Francisco cuenta con una mirada «capaz de destapar botellas» (71). Ambos actúan con inusual violencia e intervienen en fiestas donde la depravación no tiene límites; 
incluso, cazan y sodomizan a los demás internos. Hacia el término del relato, se intensifica el conflicto entre estos personajes y el Cura.

La entrada al bloque de los Celis está resguardada por dos prisioneros armados, «casi tan feos como sus cicatrices y sus tatuajes» (61). Uno de ellos recibe el sobrenombre de Sapo. El Sapo desempeña la función de Cerbero, pues restringe el tránsito entre dos esferas claramente determinadas. Dentro de la cárcel, otros elementos subrayan el paralelismo con el mundo infernal, por ejemplo, la presencia de demonios menores. Después de sufrir una golpiza a manos de los Celis, $\mathrm{N}$ es atendido por una enfermera; esta se compara con un bello «ángel sádico», es decir, con un súcubo.

En el reclusorio, N comprende que su vida pertenece a estos personajes, por cuanto nada puede hacer para sustraerse de sus designios:

No quería que me pidieran perdón. Quería que me sacaran. Hacía falta que alguien cargara la culpa, y me tocó. Hasta allí todo bien. No me iban a dar de baja, mi sueldo seguiría corriendo y me tocaba una compensación por cada mes en el reclusorio. Se iba a arreglar antes del juicio, me dijeron. Después un ascenso a teniente o algo así. Todo hubiera estado bien de no ser por el Cura y el Ciego. Bien podían haberme tocado unos compañeros mudos. O muertos (13).

Ni siquiera con la aparición del Coronel el protagonista alcanza la libertad. De acuerdo con el Coronel, un hombre que retiene e interroga a $\mathrm{N}$ para comprender su vínculo con el narcotráfico y la autoridad corrupta: «Todo estaba listo para que te murieras anoche. [El Ciego] Te iba a matar cuando estuvieras dormido. Lo de los Celis iba a tapar el relajo, pero te salvaron porque no te dormiste. Además se peleó con el otro» (26). Esto quiere decir que el comandante, superior de $\mathrm{N}$ en la policía, mintió acerca de su futuro, al parecer, movido por la lealtad ante los Celis.

En verdad, el comandante entrega a $\mathrm{N}$ como supuesto responsable del asesinato de la mujer de Francisco Celis y el extravío de una considerable cantidad de droga. La participación del narrador en un 
decomiso supone la traición de su jefe hacia el cartel y el robo de los narcóticos que pertenecen a los hermanos. $\mathrm{N}$ se encuentra entonces atrapado en medio de una guerra de bandas y una pugna entre el gran diablo y los demonios menores.

Por este motivo, el desplazamiento del narrador por el reclusorio resulta errático. Aunque el protagonista se encuentra adentro, persisten las vedas para su movimiento. En elbloque de los Celis, por mencionar el caso principal, no puede ingresar. En este sentido, a pesar de que les pertenece, no comprende sus acciones, que siempre le resultan reservadas. El empleo del deíctico «aquí» sitúa al narrador en otro espacio, en un nivel diferente al de los cabecillas del narcotráfico.

En cierto momento, lo conducen al sector de los Celis. Antes recibe una golpiza que le sirve como iniciación para el ingreso en este nuevo círculo. Tan graves son las lesiones que el protagonista compara su estadio con la muerte. $\mathrm{N}$ sostiene que se encuentra en la «boca del lobo»y no quiere «salir masticado» (71). El propósito de este encuentro estriba en allanar las diferencias del pasado, le explica el Sapo. En adelante, $\mathrm{N}$ hallará protección con ellos, a cambio debe serles de utilidad y completar algunas tareas urgentes. Por esto, definen a $\mathrm{N}$ como una víctima.

Durante seis días, el protagonista permanece en el bloque de los Celis. Los cinco primeros sucumbe al sueño e ignora lo que pasa; este suceso ratifica el simbolismo de un proceso análogo a la muerte. En la convalecencia, recibe las visitas de la enfermera: el segundo día retira las vendas; el tercero y cuarto realiza curaciones; el quinto, lo seduce. Mientras hacen el amor, $\mathrm{N}$ piensa en la apariencia de inocencia del súcubo, pero pronto descubre el engaño: «Más que un ángel perverso parecía un ángel exterminador» (93), que lo visitaba en pos de su alma. Culminado el encuentro y el proceso, el narrador camina por fin hacia las duchas; de camino ve la celda «con olor a santidad» (93) del Cura. Entra y conversa con él; la habitación le causa perplejidad, pues aunque recuerda la recámara de un monje, está decorada con gusto y muebles costosos. El Cura le muestra una caja 
de habanos veracruzanos: «La caja de puros estaba justo en medio de la litera del Cura. Parecía que lo hubiera puesto allí sólo para que me entrara la curiosidad y la abriera. No sé por qué recordé a mi primo y sentí lástima por él por primera vez» (77).

En primera instancia, se establece un importante vínculo entre el Cura y el Primo, «un pobre diablo violador y asesino». En segunda instancia, existe un tesoro, una verdad oculta que puede ser descifrada tan solo con mirar dentro del recipiente: «Si abría la caja para ver lo que había dentro a lo mejor encontraba algo que no me gustaría y me daría cuenta de que el bien y el mal no existen, y que sólo hay pobres diablos como yo y como el Cura» (78). Y continúa:

O a lo mejor había algo que me dijera que todo estaba excelente, que lo único sensato es lo que hacemos porque no hay nada más, y que ser un pobre diablo o un héroe es lo mismo, que así debe ser, que no hay culpa, que el perdón ni siquiera necesita que uno se arrepienta (79).

Para N el problema trasciende la lógica del par vivir/morir, pues se asocia con otra clase de malestar: el ético. En un ambiente regido por la utilidad, el narrador concluye: «Todo estaba tan cruzado que no distinguía donde estaba cada cosa» (78). La ausencia de referentes y de unidad, así como la violencia y el dinero acaban por convertir al mundo en un infierno para la conciencia:

Cuatro meses en el Reclusorio me habían puesto raro. Si hubiera sido otro, hubiera pensado que sentía miedo sólo de ver la calle llena de coches, los semáforos, la gente caminando. Me había acostumbrado a ser un gato encerrado en la misma lata que dos ratones locos (17).

\section{Las muertes apetecidas}

No me habían dado un arma. El comandante se había matado con la suya. Uno se acostumbra a creer que con una pistola va a estar más seguro, que la gente desarmada está siempre en peligro, pero lo del 
comandante demostraba que todo es relativo y que a las armas no les importa para qué lado disparan. Ésa es su gracia (47).

La ambigüedad del medio adopta un sentido alegórico. $\mathrm{N}$ ha cambiado su lugar en la sociedad, ha dejado de ser policía para convertirse en asesino, ha dejado de ser víctima para convertirse en verdugo, y sin embargo, prevalece el tedio. En el reclusorio, además de conocer a los narcotraficantes y sus servidores, $\mathrm{N}$ descubre otra clase de personajes. Un carcelero envejecido con una mano herida lo conduce fuera de la prisión, se trata del Coronel. Ambos suben a un viejo Mustang de color verde y llegan a un galerón vacío.

«Moví la manija y empujé la puerta. Estaba lleno de luz. Si seguía pasando de la oscuridad a la luz con tanta rapidez me iba a poner igual de loco que el Ciego» (18), indica el narrador. Este desplazamiento no solo lo aleja del Cura y los Celis, sino que lo introduce en un ámbito distinto, caracterizado por la claridad. Con todo y las connotaciones positivas, este espacio tiene una cualidad que perturba: la obsolescencia. El galerón, por ejemplo, recuerda «una escuela de ballet, pero sin espejos». El deterioro supone el principal atributo. Tanto el Coronel como su automóvil pertenecen a otra época, son casi anacrónicos. Los sitios que habita este personaje reafirman tal interpretación:

Había un despacho lleno de muebles viejos y la foto del presidente detrás del escritorio. Todo estaba lleno de papeles por todas partes: sobre los muebles, en el piso, debajo de las sillas. Pilas de papeles. También había un aparato para microfilmes en un librero y un par de cajitas de madera. Olía a cigarro encerrado y a desodorante ambiental barato. De lavanda. El estómago se me revolvió (22).

La imagen del mandatario y la presencia de escritos muestran el apego del Coronel por un sistema antiguo, en menoscabo, basado en la legalidad. Incluso, el Coronel sigue con respeto los paradigmas de la racionalidad y el proceso judicial, pues investiga y compila imágenes y declaraciones en expedientes. Su propósito consiste en 
descubrir los nexos entre los carteles y la policía; en específico, desea saber si el comandante participa en los negocios de los Celis. Para el protagonista, que carece de referentes morales, resulta atractiva una figura que sigue ideales y no obedece a los intereses ordinarios.

El Coronel tiene su mano derecha destrozada, con cicatrices moradas en lugar de dedos, mirada inquisitiva, ojos verdes, dientes tan parejos, que debían ser postizos, y actitud burlona. Es un personaje honrado, pues no asiste a las fiestas de los Celis ni toma dinero de sus negocios. Hacia el final, lo obligan a suicidarse por líos con Ortega, el jefe de otra sección, un policía que no vive de su sueldo sino de las coimas de los traficantes. Además, tiene cáncer en el hígado y este se ha extendido -por esto acepta la muerte-, se ve viejo y cansado aunque no pasa de 60 años. Su casa es modesta. Al igual que ocurre con el color de su coche y el de sus ojos, se establece una relación entre los bienes y el propietario: estos resumen su temperamento e inclinaciones. $\mathrm{N}$ describe el hogar de la siguiente manera:

Esperaba ver en su casa lo que había visto en las casas de otros jefes de policía. Pero no. Nada de pieles de animales en vías de extinción, nada de escudos de armas falsos, nada de adornos espantosos que cuestan el sueldo mensual de treinta policías rasos, prestaciones incluidas (84).

Concluye: «La casa era grande, vieja y barata, como la risa del Coronel. El barrio era un poco de lo mismo» (85). En una de las discusiones entre el narrador y el Coronel, el último indica: «Yo en tu lugar lo que menos quisiera saber es quiénes somos, y más bien me preguntaría qué chingados quieres ser» (27). Esta interrogante apunta hacia la condición de $\mathrm{N}$ y su vínculo con este nuevo sistema sin orden ni moral. Continúa el viejo policía:

-Tú crees que el asunto es de los buenos peleando contra los malos, y no va por allí. Por eso no entiendes que sea un héroe. No porque haya matado a un narco, que igual hubiera sido otra cosa, sino 
porque hice lo que tenía que hacer. Y sigo haciendo lo que tenía que hacer, por eso me voy a morir como héroe (85).

Este deber responde a modelos de conducta propios, no es un deber ante otros, no es la respuesta al mandato o la falta de coraje para revelarse ante la opresión de un orden oscuro, que enajena y retuerce voluntades. La relación del Coronel con otros personajes caracterizados por la inocencia y la bondad afianza la impresión de situarse ante una clase de seres por desaparecer; incluso, sus muertes a manos del cartel lo sancionan.

ElRonco, por ejemplo, a pesar de la apariencia tosca y la rudeza, oculta el candor propio de la infancia: «Era como un niño que cree que todo pasa porque él está allí, para molestarlo o para divertirlo. Era bueno saber que había en el mundo tanta inocencia en alguien de dos metros de alto y una cara como la suya» (39). Asimismo, el Profesor se comporta, en principio, con frialdad; no obstante, la paciencia y la ecuanimidad suponen sus virtudes. En la relación entre este hombre y el Coronel, el narrador descubre la constancia y buena voluntad del antiguo estudiante de derecho.

Como resultado del trato con estos personajes, el protagonista adquiere una nueva manera de percibir su situación: «Me habían puesto de chivo expiatorio en el peor momento: el comandante se había vuelto incómodo para los Celis, para el gobierno y quién sabe para quién más, y de seguro venía una epidemia de moralina como las que les da de vez en cuando a los que quieren una tajada del negocio» (38). Puede ahora percibir la corrupción generalizada, descubre la manera en que otros lo han utilizado.

En una conversación telefónica con el comandante, $\mathrm{N}$ entiende cuán inestables son sus vínculos con las diferentes facciones en conflicto. Esta clase de escenas, presentes con frecuencia en la serie negra, puede interpretarse como una metáfora de la complejidad de la comunicación; el teléfono y la distancia vuelven ambiguo el intercambio de noticias, por cuanto no se percibe la gestualidad. 
De vuelta en la cárcel, a manos de los carteles, el narrador experimenta la muerte, pues estos lo hacen aparecer como uno más de los suicidas -es decir, de aquellos que el narcotráfico asesinó-. En el diario se incluye una nota sobre su falso fallecimiento: «En la foto del periódico lo único fuera de lugar era la mancha de sangre alrededor de la cabeza, la pistola cerca de la mano y los ojos abiertos. Me veía tirado en el piso, boca arriba, como bebé ciego o como tortuga asustada» (55). La prensa afirmó que, tras escapar de la cárcel, mató al comandante por deudas del narcotráfico; luego, rodeado por la policía, se quitó la vida.

\section{La muerte y el orden}

Tenía una mancha en el estómago. Le aparté la chamarra y la camisa. Olía a mierda. Seguro tenía perforado el intestino. La muerte será lo que quieran, pero siempre hay mierda de por medio (14).

Lanoveladespliegaun proceso. Enlaprimeraetapa, elpersonajeinvestigador debe penetrar en la lógica de un mundo vedado para él; en la segunda etapa, muere para sobrevivir. Deviene lógico pensar que el narrador protagonista ha debido modificar profundamente su conducta y mentalidad para adecuarse a las circunstancias de un mundo ajeno a los sistemas morales tradicionales, y dominado por el culto al dinero, la mentira, la corrupción y la violencia. En estos términos, la novela desarrolla una alegoría acerca de la caída del orden social y el Estado, como consecuencia del ascenso del narcotráfico.

El sentido alegórico resulta evidente en dos sentidos. Por un lado, en la ausencia de nombres específicos para los personajes (mediante la designación familiar-Primo, Abuela, Madre-, laboral o gremial-Coronel, comandante, Cura, Profesor-y de cualidades -Ronco, Ciego-); por otro, en el despliegue de un imaginario cosmogónico acerca de la lucha entre el bien y el mal, previa al nacimiento de un nuevo mundo. El motivo asociado con el descenso al infierno plantea, cuando menos, 
dos posibles significaciones: la primera, que el personaje se degrada y entra en conocimiento de la faceta oscura e incierta del entorno; la segunda, que debe convertirse en algo distinto a lo que ha sido.

El tema acerca de la dualidad coliga con la representación de la crisis y fractura del orden, y la emergencia de un mundo venidero. Según explica Cohn ${ }^{11}$, en este punto, la herencia cultural cristiana y occidental se nutre, ante todo, de creencias egipcias, zoroástricas y judías. Tales especulaciones teológicas han alimentado diversos movimientos milenaristas acerca de la caída del mundo y su descenso al caos. Estos idearios apocalípticos trascienden la esfera de lo religioso; en ocasiones, como ocurre con el legado marxista-leninista, brindan nociones acerca de la historia ${ }^{12}$.

Las representaciones del combate entre el orden y el caos proceden, incluso en la época contemporánea, de ese rico conjunto de imágenes religiosas. En la actualidad, la promesa acerca del final del sufrimiento y la redención sufre profundas transformaciones como consecuencia de las premisas imperantes en la sociedad posmoderna. El desencanto y la desconfianza frente a los procesos revolucionarios acentúan la imposibilidad de alcanzar el paraíso, que el proyecto ilustrado situó también al final de la historia. El orden sucumbe porque los ideales son inalcanzables.

En opinión de Bull ${ }^{13}$, la tesis acerca del final de mundo suele estar correlacionada con otra acerca de su finalidad; porque todo persigue un propósito, luego fenece. Esto es, porque el mundo cumple una misión, esta ha de consumarse en algún momento. La imaginación moral concibe al universo, plantea Bull, a partir de esta circunstancia: se piensa en el desplome cósmico como confirmación de la ausencia de destino.

11 NormanCohn, Elcosmos, el caos yelmundo venidero.Trad.B.Blanch(Barcelona:Crítica, 1995) 238. 12 Cohn, 246.

13 Malcolm Bull (comp.), La teoría del Apocalipsis y los fines del mundo. Trad. M.A. Neira (México: Fondo de Cultura Económica, 1998) 11. 
La tribulación fomenta las percepciones de decadencia. En pasajes críticos, la vida social de un determinado país puede ser concebida mediante relatos cargados de decepción. Cercana al tono del mito, la novela plantea el acabamiento de la unidad social en México, asícomo el surgimiento de una realidad radicalmente diferente; otra manera no de vivir, sino de prevalecer, de escapar a la «vocación de víctima», para transformarse en victimario, un ser libre de cualquier pauta de conformidad pero también desligado por completo de los demás.

$\mathrm{Al}$ acudir al empleo de temas asociados con lo sobrenatural, el novelista demuestra una suerte de sed por lo fantástico. Esto no supone una novedad. La ficción criminal, aunque emparentada con el racionalismo puro, también se alimentó del espíritu gótico prevaleciente en las letras del siglo xix. Edgar Allan Poe escribió los primeros cuentos policiales a la par de sus relatos acerca de eventos extraordinarios. El decadentismo, los amores turbios y la representación de la maldad ocupan un lugar privilegiado en las páginas de esta variedad narrativa.

Cualquier forma de morir incluye numerosas alusiones al mal; en lo puntual, al diablo y los demás demonios de su corte. Este «retorno de lo superado», como lo denomina Muchembled ${ }^{14}$, implica el restablecimiento de creencias religiosas que habían sido rechazadas por la razón. Según piensa el historiador francés, al lado de la angustia existencial y el malestar, la práctica descrita corresponde con una percepción lúdica y escéptica del mundo moderno.

Una de las señales de este gusto por el juego y lo asombroso se halla en la utilización de una antigua fórmula literaria: el motivo del doble. Este elemento afianza la primacía de la muerte como mecanismo del cambio y sostén de la nueva organización. Tras el aporte del psicoanálisis, el tema de la duplicidad varió, señala Bargalló ${ }^{15}$;

14 Robert Muchembled, Historia del diablo. Siglos xii-xx. Trad. F. Villegas (México: Fondo de Cultura Económica, 2002) 316.

15 Juan Bargalló, Identidad y alteridad: aproximación al tema del doble (Sevilla:Alfar, 1994) 11. 
en la actualidad, la presencia de personajes dobles se entiende como indicio de la proximidad de la muerte.

El Primo del narrador era torpe y enfermizo; por esto, las otras personas sienten lástima por él. Estas consideraciones acabaron por convertirlo en un ser perverso, pues descubre cuánto provecho se logra obtener de la caridad. Flaco, siempre con la nariz sangrando y mentiroso, recibía un trato de excepción: «Pobrecito, decían los profesores, y nunca le dieron menos de siete de calificación, con todo y que apenas sabía escribir y que se tardaba horas cuando la abuela lo mandaba a la tienda porque lo confundía que las monedas y los billetes no valieran lo mismo» (30).

Para N, su pariente supone, durante la infancia y la adolescencia, un engaño pero también una amenaza, pues abusa sexualmente de la mitad de los primos menores que él, sin importar la edad ni el sexo. Incluso, durante un episodio violento, el Primo perfora con un gancho el útero de su hermana de once años, pero la Abuela y la Madre sostienen que él no tiene responsabilidad de su comportamiento. Enfermo del cuerpo, de la moral y la mente, esta figura personifica la perversión. En la vida adulta, tal actitud no se modifica; por encima de los cuarenta años, deambula entre médicos y mafiosos:

Cuando no estaba en el hospital se metía a jugar cartas en lugares a los que daba escalofrío acercarse. Jugaba póker, veintiuno, brisca, gin, canasta, lo que fuera. A veces ganaba un poco, a veces perdía mucho, y siempre había alguien que le pagara las deudas, que se las perdonara o que sólo le rompiera una costilla o una pierna que de todas maneras se iba a quebrar. Y todavía le alcanzaban el tiempo y las energías para hacer cosas sucias (32).

Acerca del comandante, indica N:

Mi comandante se parecía a mi primo en casi todo, excepto en las paperas y los huesos débiles. También se la pasaba sangrando por la nariz, pero no porque estuviera desnutrido, sino porque se metía 
todo por allí. Y no sólo por allí. Tenía las mucosas de todo el cuerpo hechas una desgracia y se las ingeniaba para ayudar a que otros también se las jodieran. Lo malo fue que le caí simpático y decidió que fuera su mano derecha. Lo bueno fue que el comandante era zurdo (33).

La ironía del protagonista pone de manifiesto una analogía entre elorden familiar, adulterado por el Primo, y el orden nacional, corroído por las acciones del policía dedicado al tráfico de drogas. Ambos Primo y comandante- comparten diferentes atributos; así, una frase a propósito del último bien puede ser útil para retratar al primero: «Si el tipo tenía moral nunca la había usado» (33). El comandante destruye a los Avendaño, gana prestigio y lo condecoran, pero en verdad lo hace para ayudar a los Celis (34); luego, traiciona a los Celis, pues el ansía de enriquecerse lo impulsa a jugar con los carteles.

En la tercera sección del texto, el narrador refiere los hechos conducentes a la muerte del Primo. Después de cuatro años sin noticia, el Primo vuelve a la ciudad con motivo de los funerales de la Abuela; allí se encuentra con $\mathrm{N}$, ambos conversan y terminan jugando póquer en el apartamento del policía. La molestia del protagonista se agudiza cuando descubre que el Primo, a pesar de las atenciones ofrecidas, hace trampa en el juego. Discuten entonces y N lanza al hombre desde el sétimo piso. En aquella ocasión, el narrador enfrenta tanto a la justicia como a la familia:

Creí que los primos me llevarían en hombros por las calles y me levantarían una estatua. Me equivoqué. Desfilaron por mi celda, pero no para darme las gracias, sino para decirme que era un criminal que no merecía perdón, que el primo era un pobre enfermo, que la abuela se hubiera muerto otra vez. Eso quería decir que yo casi era el asesino de la abuela. Había acabado con su villano favorito (36).

La lección aprendida parece simple de explicar: las apariencias causan confusión. En respuesta, el protagonista afirma: «No muy en el 
fondo los primos siempre me habían aburrido. Lo único que los hacía interesantes era que el Primo los hubiera violado o que se hubieran escapado de que los violara. Muerto el perro se le acabó la gracia» (37).

Las meditaciones sobre el imperio de la muerte y la forma en que los demás participan concluye de esta manera: «En el fondo todos los héroes son tan pendejos como el resto de la gente, y por eso hay tantos en los panteones y en los libros de texto»; «Si alguien le hubiera dicho a la mayoría de los héroes lo que iba a pasar, seguro deciden morirse de viejos y el mundo tendría menos nombres para acordarse en la escuela» (65).

Puesto que la moral ha cedido, el heroísmo deviene ridículo; la única tarea realmente importante consiste en encontrar el medio para postergar la propia muerte. En este sentido, $\mathrm{N}$ entiende cuán poco ofrece su perfil de espectador: «Estar en un balcón mientras partían por la mitad a otro comandante me pareció bien, pero me sentí como el tonto de la familia al que le encargan que lleve la puntuación mientras los demás corren, meten goles y se divierten» (69).

En un pasaje previo, se refiere al orden social y los ajusticiamientos como un juego, una competencia (crímenes como fútbol), donde él solo observa. «Me fijé una regla estricta: yo no iba a ser el muerto» (69), advierte. Para el narrador, la ausencia de heroicidad delimita a la nueva época; aquellos que la quisieron conservar han fallecido, entre estos, el Coronel:

-Yo nunca fui a sus pendejas fiestas -me dijo el Coronel mientras limpiaba su cuarenta y cinco, porque quería matarse con una pistola limpia-. Si por eso me he de morir, me muero, qué chingados. Tampoco agarré un centavo de sus negocios. Siempre he vivido de mi sueldo y con mi sueldo voy a pagar el funeral, la misa, la caja y el panteón (81).

Yaal final, $\mathrm{N}$ desempeña la función de emisario del nuevo orden. Para cumplir con su papel y profundizar en los círculos del infierno, donde contempla violencia y depravación, debe participar del sistema: 
se convierte en asesino, mata por furia al Primo, y no por sentido del deber como había ocurrido con la mujer de uno de los hermanos Celis. Traicionar a sus amigos es la prueba siguiente, únicamente los traidores están a la diestra del demonio.

Antes de verse compelido al suicidio, el coronel medita acerca del heroísmo y su exclusión en el nuevo orden. Desde su perspectiva, no existe lugar ya para quienes ofrecen su vida a favor de los demás; en adelante prevalece el más crudo egoísmo. Este personaje plantea una interrogante al narrador: ¿seguirá como pieza de la maquinaria o no?, ¿será un testigo del cambio o actuará? Este elemento da lugar al tipo de narración, en primera persona, pues se construye como testimonio de un cambio que afecta al mundo exterior y a la conciencia delpersonaje.

El Coronel deja una nota aclaratoria: «Me mató Ortega» (87), acusa. En estos términos su muerte se debe a la acción de su doble, un policía corrupto que no vive de su sueldo ni cumple con sus responsabilidades. El objetivo de esta carta supone el deseo por alcanzar una muerte inmaculada, no asociada con el narcotráfico. Incluso, en el desenlace de una vida cabe la posibilidad de conservar el decoro. $\mathrm{Su}$ rechazo a la inercia de la maquinaria alerta acerca del término de una ética en desuso.

El narcotráfico actúa como un autómata, solo utiliza a los hombres, los aliena y destruye. La mafia funciona como una enorme maquinaria, así lo señala el Cura:

En lo que averiguábamos qué chingados pasaba hubo que cuidar que la pinche máquina no se detuviera, y en el camino se fue gente que no tenía que haberse ido. El Ciego no es nada. El Ciego es pendejo. El culpable soy yo, y ni modo. Te digo algo: aquí el que se queda quieto, se chinga, lo aplasta la máquina. Las cosas hubieran pasado igual contigo o sin ti, si te hubieras muerto o si no hubieras nacido (99).

Ni siquiera los líderes de los carteles escapan de esta lógica. En medio de la pugna por el poder, Francisco Celis asesina a su hermano 
y el narrador, al Cura. Resuelto el lío por el poder, Francisco pide que lleven al narrador al aeropuerto para que, en pago de los favores, tome un vuelo hacia algún pueblo lejano; le advierte que no quiero verlo de nuevo, pues si no tendrá que exterminarlo.

Al final, $\mathrm{N}$ parte hacia Tijuana, donde se esconde por más de cuatro meses. En esa ciudad N y el Sapo se encuentran. Conversan entonces acerca de la muerte de un candidato involucrado con el trasiego de estupefacientes y la mafia. El protagonista ha logrado aplazar la muerte, aunque ahora le pertenece a ella más que nunca.

\section{Epílogo}

Durante la última década del siglo xx, hubo significativos cambios en la narrativa hispanoamericana. Esta transformación de la sensibilidad es tan intensa que bien puede hablarse de una ruptura de los códigos. En el nivel temático, el proceso de separación se descubre en el desplazamiento hacia tópicos nuevos y en el abandono de la perspectiva «identitaria». Por lo demás, esta transformación se corresponde con el auge de la irracionalidad y el retorno de una imaginación fundada en el mito.

La novela contemporánea se concentra en la ciudad. Para la narrativa estrictamente actual, la pregunta por el pasado y la identidad carece de sentido si se la separa del individuo. Los narradores prefieren centrar su interés en los seres concretos y no en los amplios procesos sociales e históricos que explican el origen. Para los escritores nacidos a partir de 1950, Hispanoamérica debe ser vista y representada por el escepticismo y la fragmentación. Las fábulas acerca de sus ciudadanos han de contar la historia no de una estirpe condenada a la soledad, sino de una comunidad amorfa, enajenada, desigual y acosada por la injusticia y la corrupción política.

El mundo descentrado de la posmodernidad se entiende, en estas latitudes, como un lugar donde los valores de base están ausentes. Esta clase de novela retrata a personajes derrotados y solitarios; a figuras 
sin rumbo, incapaces de comunicarse con los demás, salvo de manera ocasional y violenta. A causa del supuesto «fin de la Historia», las aspiraciones de estos curiosos héroes se tornan no solo obsoletas, sino absurdas. La nostalgia, marca contemporánea del pensamiento simbólico, determina un discurso en el que la historia se ve falseada.

Como consecuencia del ocaso de las ideologías, esta novelística rehúye el tema de la utopía y prefiere el análisis del presente inmediato. Como es de esperar, con todo y las profundas modificaciones, la novela contemporánea no deja de ofrecer sugestivas alegorías acerca del orden social y su deterioro. Al entender la historia como una realidad no lineal, los narradores se permiten imaginar las circunstancias sociales bajo el modelo del círculo y el mito, es decir, del agotador retorno. El mito y el arquetipo ofrecen esquemas no racionales, maneras de acceder al conocimiento de una sociedad rota en sus aspiraciones y cargada de cinismo. La violencia, la corrupción política y el deterioro social generan incertidumbre.

Los escritores recrean ese ambiente de decadencia y plantean fábulas milenaristas acerca del fin del mundo. Este conocimiento acerca del mundo ha de ser interpretado con escepticismo. La novela propone una comprensión de la historia según los parámetros actuales. Si lo irracional domina la historia; luego, el peso de los hombres y sus voluntades es restringido. Pintar el mundo en arreglo a dos principios, primacía de lo irracional y término de la historia, corresponde no solo con la maniobra política, también se lo puede comprender como un táctica comercial. La novela negra ocupa un lugar privilegiado entre las variedades literarias destinadas al consumo masivo. La estética del éxito de ventas supera el ámbito del estilo; se relaciona con la sensibilidad del público. Gusta mucho a los lectores este tipo de libros, que suman protagonistas, intrigas y enigmas, que prometen acercar al receptor a la historia, pero bajo modelos familiares, modelos en lo que resuena la influencia de antiguos relatos míticos. 